\title{
Environmental discourse (from the journalistic sphere) and its recontextualization in Brazilian textbooks to teach English ${ }^{1}$
}

\author{
Amanda Poliane Silva* \\ Vera Lúcia Cristovão**
}

\section{Summary}

This article aims at investigating texts that approach environmental discourses in textbooks for English language teaching and their implications in education. The data are selected by means of i) gathering of texts in the book collections approved by PNLD 2015; ii) identification of the environmental perspective and its characteristics among the selected texts regarding genre, support, theme, and context of production. The results demonstrate that the rational perspective is predominant among the texts disseminated, the institutional type of support was the leading format and the majority of them came from inner circle sources. As for implications, we emphasize: i) the use of images may promote the opportunity for(critical) literacy fostering the construction of new meanings; ii) the predominant texts from the inner circle sphere distance the student from peripheral perspectives and the English language use as international or so called "língua franca"; iii) the focus on the rational perspective keeps technical or technological actions as the solution for environmental problems.

Key words: environmental discourse; journalistic sphere; didactic material; English language.

* Graduada em Letras pela UEL. E-mail: amanda.poliane.silva@gmail.com

** Professora associada da Universidade Estadual de Londrina (UEL), membro do Programa de Pós-Graduação em Estudos da Linguagem (PPGEL-UEL) e líder do grupo de pesquisa Linguagem e Educação (desde 2002). Graduada em Serviço Social pela Universidade Estadual de Londrina (1988), mestre (1996) e doutora (2002) em Linguística Aplicada e Estudos da Linguagem pelo Programa de Pós-Graduação da PUC-SP. Recebeu bolsa-sanduíche Capes para realização de parte de sua pesquisa de doutorado na Faculdade de Psicologia e Ciências da Educação da Universidade de Genebra em 1999/2000. Tem estágio de Pós-Doutorado (2007-2008) no Programa de Pós-Graduação da PUC-SP e do PPG em Estudos Linguísticos da UFMG em 2012. Teve bolsa da Capes/Fulbright como professora pesquisadora na Universidade da Califórnia, campus de Santa Barbara, de outubro a dezembro de 2012. Tem experiência na área de Linguística Aplicada, atuando principalmente nos seguintes temas: gêneros textuais, educação inicial e continuada de professores de línguas, ensino de língua estrangeira e estudos de produção textual. Foi bolsista de Produtividade em Pesquisa pela Fundação Araucária de 2008 a fevereiro de 2013. É bolsista de Produtividade em Pesquisa do CNPq desde março de 2013. E-mail: veraluciacristovao@gmail.com

Data de submissão: jan. 2019 - Data de aceite: mar. 2019 http://dx.doi.org/10.5335/rdes.v15i1.9017 


\section{Introduction}

Discourse studies are recognized as being extremely interdisciplinary areas of study which underlie the notion of discourse as an exercise of power. By analyzing discourses in their possible forms in society, a research work may notably take a "multi-modal" approach to examine how written, spoken and visual modes of communication (inter) act in different spheres.

A well-known topic of inquiry is the environmental discourse that may circulate in different discursive domains. In this paper we focused on the environmental discourse that circulates in the school sphere through its presence in textbooks for English teaching in Brazil.

This article is based on Bazerman's theoretical assumption (2009) that teachers act as mediators of literacy encounters on the use of texts, written or oral, which hold knowledge about environmental issues that can reveal the intertextuality of prior texts, as well as to promote the reader's consciousness and commitment regarding the natural environment conservation.

The National Environmental Education Foundation (NEEF) of the United States describes that the use of language teaching to teach environmental themes may help develop critical thinking, improve science, raise environmental awareness, and environment literacy at last, to use the knowledge into action. Likewise in Brazil, based on the guide- lines issued by UNESCO, in April/1999, the National Policy for Environmental Education (NPEE) was released recommending that environmental education (EE) should have a humanist focus, consider the correlation among the natural, socio-economic and cultural environment, and respect the pluralism of pedagogical conceptions, the ethics code and cultural diversity (BRASIL, 1999). UNESCO guidelines propose EE as a process that progresses from awareness, comprehension, concern, skills development to prepare for solutions and participation.

Therefore, we believe the integration between English Language teaching and environmental issues may contribute to one's awareness and comprehension of aspects related to the protection of the environment, in addition to arousing attitudes which concern and transform habits in order to have a friendly environmentally behavior.

Thus, based on the assumption that the classroom is a locus responsible for building social representations about the world and, consequently, about the environment, it is important to analyze the texts students will interact with, in order to learn. Considering that the social representations are reinterpreted and transformed in language actions, the present paper aims to investigate the environmental discourse on the didactic collections to teach English in Secondary Education in Brazil. Consequently, it is crucial to understand this textual-dis- 
cursive composition and its implication in language education.

Our data were gathered from four didactic collections approved by the $\mathrm{Na}$ tional Program of the Didactic Book for secondary school for the period of 2015 , 2016 and 2017. Our specific objectives are: i) to identify the themes, genres and support of the texts that convey environmental discourses on these didactic books and ii) to recognize the view of environment/ideologies underlying such texts and the concept of readerly or writerly texts.

This paper is organized as follows. The first section is a brief overview of the main concepts. The second section describes the methodology. The third section is dedicated to the presentation of the results and the discussion. Our conclusions are drawn in the final section.

\section{Literature Review}

Since the 60's, environmental problems have been a matter of discussion, as "The silent spring" by Rachel Carson has shown. In her seminal book of 1969, she points out problems about the use of insecticides in agriculture. Since then, the XXth century was marked by reunions and conferences regarding the environment, and these initiatives present the importance of learning and acting as a society, to protect nature in general.

Due to the global concern among political and public authorities, various institutions have disseminated informa- tion regarding the subject. The Belgrade Letter, in 1975, was produced in Yugoslav by many specialists from various areas of research, and it gathered the six goals of Environmental Education. The United Nations have sponsored scientific panels, such as The International Panels of Climate Change (IPCC) that hold results about the "changes and causes; future climate change, risks and impacts; future of adaptation paths, mitigation and sustainable development; adaptation and mitigation".

Subsequently, in April 1999, the Environment Education National Policy was instituted in Brazil, according to the law number 9.795, which has guaranteed that every stage of education must encompass inter, multi and transdisciplinary environmental questions on the pragmatic content. Thus, it is only natural that language could contribute to the understanding of this transformed scenario, built by social representations regarding the environment and its interaction with society.

Language is used to convey concepts of nature and of environmental education. There are several definitions for environmental education with underlying ideologies. According to Tozoni-Reis (2004), environmental education can be divided into three kinds: natural, reasoning/radical and historical.

The natural perspective addresses the idea that men and nature should go back to a primeval balance, where their relationship does not affect or cause any damage to the earth, in some ways, presented as a philosophical view. 
The first perspective indicates equality among all nature elements to return to a natural equilibrium. This perspective refers to the idyllic character of men-nature relationship: the humans are represented as the villains whose in need of finding themselves back to their natural place. It is a romanticized conception, in which the suggested idea is to go back to the paradise. (Tozoni-Reis, 2004, p. 29)

The second perspective presented in the book is the rational, where men have a conscious relationship with nature, and technology is a tool used to overcome all environmental problems.

The second tendency is found at the representation of human-nature, which acknowledges the inequality presented among them, pointing the lack of knowledge about the natural laws as the reason for the environmental problems. In this case, knowledge is the men-nature mediator, thus an immediate, direct, automatic, and mechanic mediator, such as: learned....preserved. This perspective refers to the utility character among the people and their environment: to know (technical and scientific knowledge) how to use, to keep using even more, and always. (Tonozi-Reis, 2004, p. 29)

The last one defines the relationship between history and culture as the result of social encountering, where men and nature dialogue throughout the social changes, characterizing it as the historical perspective.

( )...men-nature are presented as historical conditions, social, political, economic, and cultural. This relationship is comprehended as the perspective of society-nature. The main idea is that the perspective is built on social relations: the history and culture are conditioned and mediators, given its social-historic character. (TONOZI-REIS, 2004, p. 25)
Furthermore, Tozoni-Reis (2004) reports the technical and scientific knowledge to be an important part of the society-nature, for the historical perspective, ensuring that it is only possible when analyzing the relation among culture, society and history. So, in order to identify the perspective underlying the texts selected from the materials, we rely on the analysis of contextual and textual characteristics. With the purpose of carrying out such investigation, we selected some concepts which will be explained thereafter.

Therefore it is appropriate to agree with Hall (2001) when they affirm that analyzing policies is necessary to investigate the possible effects that they may cause in the construction of meaning by the citizen (reader). For that reason the analysis should begin with the identification of the (historical and political) context.

Bearing this in mind, the Policy Cycle Approach (PCA), based on Stephen Ball and Richard Bowe's work (1992), indicates the necessity to articulate more educational policies in a macro and micro level. The use of PCA is a feasible alternative for this type of analysis, since it gives the opportunity to work a tridimensional form of research, not linear, going from theory to practice.

The three variations classified as the main guide for this approach are the context of influence, where the public policies are created, the influence context which involves for example the 
government, the scientific community and some specific social status. The production context is where the texts are developed, actually written and regulated. The third context is where the practice takes place, the interpretation and signification of the policy discourse is re-created, according to the view of those who are accessing the texts.

Regarding the professional accountability in the formulation process and policy implementation, it is cited the writerly (reader as co-writer) and readerly (reader as an inert consumer) method. These two types of texts are the product of a policy formulation process, considering that the texts are intertwined with the contexts they were developed in. Therefore, it shows the value of a research over this subject in the Brazilian context. Based on the concept of readerly and writerly texts by Barthes (1981), Hall (2001) explains that a readerly text limits the reader to consume meaning given by the author rather than who produces it. It means that the text's main characteristic is to give not a draught for question and unambiguous instruction. In contrast, a writerly text invites the reader to co-produce meaning by interpreting widely and not controlling the reader.

As one of the methods used to analyze texts, the Sociodiscursive Interactionism (SDI) defends the social character of human activity, psychic development, and the language important role and work performed in meaning making, as well as the necessity of a constant resilience about cultural establishments to transform the social environment and one self.

The Sociodiscursive Interactionism (SDI) is a theoretical and methodological frame of study for the processes implied in textualization in articulation with the various current tendencies that have evolved from Social Interactionism, or that adhere to its fundamental principles. It is defined as a science of the human, whose main principles rely on the assumption of the crucial role of language in the development of conscious thought, and on the role that language assumes at later stages of peoples' development, in the epistemic and praxeological areas of that same development.

Language units can characterize the communicative activity, built by language actions in social practices related to the activity spheres, regarding the praxeological action, constituted by the practical acts that help to build a society, and they are: the objective, social and subjective. The analysis takes us to interpret the action and the type of acting.

Therefore the SDI approach analyzes broadly the social historical context where the text was produced and the production condition, hence the available information about the physical and social context, in which the texts belonging to the genres taught are developed, furthermore our representation about the data which is not accessible. To enhance the understanding of the discursive language of the texts it is vital to overview 
the concept of genre and genre-based approach for pedagogical practices

Within this theoretical-epistemological approach, Bronckart (1999, p. 121) defines genres as "the various culturally oriented ways of constructing and organizing significations (or meanings)". Cristovão (2015) recaps such definition and develops it.

Genres are language practices embodied in texts and recognized as social practices. Genres are responsible for an individual's social insertion in different activity spheres (DOLZ; SCHNEUWLY, 2004), and it is through language practices within genres that people produce, comprehend and interpret meanings. Genres are also sociocultural, purposeful and situated pre-constructs and may be partly recognized by their linguistic recurrent aspects".

In order to comprehend where most of the texts approaching environmental discourse come from, the study analyses the support used to host the text chosen for the English textbooks, regarding natural environment. The support identifies where the text is, therefore Bonini (2011) implies that "the support is mainly a text holder, however it is not a transportation or vehicle method, nor a static support, it is rather a locus in which the text is attached and replies over the genre supported". Bonini (2011) brings this definition by analyzing Marcuschi's (2002) idea of what support is and its importance on genre. Furthermore it is correct to say that the genre and support are independent elements, their relationship establishes only the text format and the meaning regarding the support where it is presented.

The support gives an idea of where to find the English materials that are presented in the textbooks, but does not fulfill the research, thus the type of support deepen the understanding of other important analyses. Looking at a macro point of view, there are three main categories of support; institutional, media, and community. The institutional site takes the information from one point to the other. It is developed for commercial purposes, although it is also created for non-profit institutions. One could find this type of support at business, services, contacts, government and non-profit organizations websites. However a media website feeds constantly with new information, it is dynamic and interactive, in this category the reader can see some news, magazines, blogs, flogs, and etc. The other support presented is found in community sites, and they are easy to identify because they are used as mechanisms to interact with others, such as Facebook, Myspace, forums, chats, and others.

\section{Method}

The research is predominantly qualitative (RICHARDSON, 2007) within document analyses (TOZONI-REIS, 2004), with some quantitative analyses. The textbooks selected for analyses 
were approved by the National Textbook Program $^{2}$ (PNLD) for high school use during the period $2015-2017$. The main requirements to approve the books were the ones below:

1. Gather a number of texts which represent the foreign language speaking communities, with adequate themes, where there are no stereotypes or prejudice regarding the foreign cultures involved, and our own relations with them;

2. Select texts which help the access to cultural diversity, social, ethnic, age groups and gender, presented in the foreign language, ensuring the comprehension where the diversity is intrinsic to the language construction and the communities it represents.

3 . Include varieties of genres, materialized by verbal and non-verbal language, characterizing different ways of expressing the foreign and first language of the learners.

4. Include texts which circulate in the social world, originating from different spheres and support representing those communities that are expressed in the foreign language.

5. Expose social and historical elements underlying texts in a way to provide room for understanding the production and circulation conditions.

6. Discuss the intertextuality relation from the expressed production either in the foreign or student's first language.

Based on these criteria, there were four collections approved by PNLD 20152017, which we named as A, B, C and D, and they are composed by three levels each with 8 units per year, as table 1 presents.

Table 1 - Book collections division by units and number of texts identified.

\begin{tabular}{l|c|c|c|c}
\hline \multicolumn{1}{c|}{ Collections } & A & B & C & D \\
\hline $\begin{array}{l}\text { Number of Units/Number of } \\
\text { Books }\end{array}$ & $\begin{array}{c}\text { 8 units per book } \\
\text { 3 books }\end{array}$ & $\begin{array}{c}\text { 8 units per book } \\
\text { 3 books }\end{array}$ & $\begin{array}{c}8 \text { units per book } \\
\text { 3 books }\end{array}$ & $\begin{array}{c}8 \text { units per book } \\
\text { 3 books }\end{array}$ \\
\hline $\begin{array}{l}\text { Number of analysed texts } \\
\text { by collection }\end{array}$ & 24 & 43 & 80 & 19 \\
\hline $\begin{array}{l}\text { Number of analysed images } \\
\text { by collection }\end{array}$ & 4 & 15 & 30 & 11 \\
\hline
\end{tabular}

Source: the authors 
The research procedures began by analyzing the PNLD 2015's approved collections conveying texts about environmental issues. A total of 177 texts was identified as covering the topic without including the opening pages, which were about 2 pages with pictures and titles. Not all three levels of each collection presented units specifically about the environment as some of them were found as subtopics and others as the main subject of a unit.
For the qualitative analysis, the following procedures took place: i) the texts approaching environmental discourse, in terms of the dominant ideologies, and questioning about the ones left out; ii) gathering of presented texts in the didactic materials that came from the media sphere. Table 2 shows the objectives, the data and the procedures of analyses.

Table 2 - Method used to analyze the texts

\begin{tabular}{l|l|l}
\hline \multicolumn{1}{c|}{ Objectives } & \multicolumn{1}{c|}{ Data } & \multicolumn{1}{c}{ Analysis Procedure } \\
\hline $\begin{array}{l}\text { i) to identify the themes, genres } \\
\text { and support of the texts that con- } \\
\text { vey environmental discourses } \\
\text { in Brazilian textbooks to teach }\end{array}$ & $\begin{array}{l}\text { Texts about the environ- } \\
\text { ment in Brazilian textbooks } \\
\text { to teach English approved } \\
\text { bnglish }\end{array}$ & $\begin{array}{l}\text { Identification of the theme, genre, } \\
\text { support by investigating the sour- } \\
\text { ce, the purpose of the text, the } \\
\text { 2017. }\end{array}$ \\
$\begin{array}{l}\text { ii) to recognize the view of envi- } \\
\text { ronment/ideologies underlying } \\
\text { such texts and the concept of } \\
\text { readerly or writerly texts. }\end{array}$ & $\begin{array}{l}\text { topic within environmental issues } \\
\text { and the source. } \\
\text { Identify the environmental educa- } \\
\text { tion perspective considering the } \\
\text { type of text, the genres, sources } \\
\text { and its recontextualization to the } \\
\text { textbook. }\end{array}$ \\
\hline
\end{tabular}

Source: the authors 


\section{Results and discussion}

The units and texts were guided by themes, presented by collection and level in Table 3.

Table 3 - The themes divided by collection and level

\begin{tabular}{|c|c|c|c|c|c|c|c|}
\hline Grand Total & Total & A & $B$ & $\mathrm{C}$ & $\mathrm{D}$ & Book Level & Themes \\
\hline \multirow{3}{*}{74} & 55 & 15 & 9 & 30 & 1 & 1 & \multirow{3}{*}{ Reduce/ Reuse/ Recycle } \\
\hline & 1 & & & 1 & & 2 & \\
\hline & 18 & & 11 & & 7 & 3 & \\
\hline \multirow{3}{*}{23} & 2 & & & & 2 & 1 & \multirow{3}{*}{ Pollution } \\
\hline & 2 & & & 2 & & 2 & \\
\hline & 19 & & 9 & 1 & 9 & 3 & \\
\hline \multirow{3}{*}{19} & 3 & 1 & & & 2 & 1 & \multirow{3}{*}{ Deforestation } \\
\hline & 0 & & & & & 2 & \\
\hline & 16 & & 2 & 14 & & 3 & \\
\hline \multirow{3}{*}{17} & 0 & & & & & 1 & \multirow{3}{*}{$\begin{array}{c}\text { Climate Change/ Global } \\
\text { Warming }\end{array}$} \\
\hline & 14 & & & 14 & & 2 & \\
\hline & 3 & 1 & 1 & 1 & & 3 & \\
\hline \multirow{3}{*}{10} & 4 & & 2 & 1 & 1 & 1 & \multirow{3}{*}{ Sustainability } \\
\hline & 1 & & & 1 & & 2 & \\
\hline & 5 & 2 & 2 & 1 & & 3 & \\
\hline \multirow{3}{*}{8} & 3 & & & 1 & 2 & 1 & \multirow{3}{*}{$\begin{array}{c}\text { Environmental Protection/ } \\
\text { Awareness }\end{array}$} \\
\hline & 0 & & & & & 2 & \\
\hline & 5 & & & 3 & 2 & 3 & \\
\hline \multirow{3}{*}{7} & 0 & & & & & 1 & \multirow{3}{*}{ Extinction } \\
\hline & 0 & & & & & 2 & \\
\hline & 7 & & 3 & 4 & & 3 & \\
\hline \multirow{3}{*}{6} & 5 & & & 5 & & 1 & \multirow{3}{*}{ Go Green } \\
\hline & 0 & & & & & 2 & \\
\hline & 1 & & 1 & & & 3 & \\
\hline \multirow{3}{*}{4} & 2 & 1 & & 1 & & 1 & \multirow{3}{*}{ Natural Env. Problems } \\
\hline & 0 & & & & & 2 & \\
\hline & 2 & 1 & 1 & & & 3 & \\
\hline \multirow{3}{*}{4} & 1 & 1 & & & & 1 & \multirow{3}{*}{$\begin{array}{l}\text { Human behavior and } \\
\text { Environment }\end{array}$} \\
\hline & 0 & & & & & 2 & \\
\hline & 3 & 1 & 2 & & & 3 & \\
\hline \multirow{3}{*}{2} & 1 & & & & 1 & 1 & \multirow{3}{*}{ Alternative Energy Source } \\
\hline & 0 & & & & & 2 & \\
\hline & 1 & & & & 1 & 3 & \\
\hline \multirow{3}{*}{1} & 1 & & & & 1 & 1 & \multirow{3}{*}{ Science and Technology } \\
\hline & 0 & & & & & 2 & \\
\hline & 0 & & & & & 3 & \\
\hline & 1 & & & & 1 & 1 & \\
\hline 1 & 0 & & & & & 2 & Market and Production \\
\hline & 0 & & & & & 3 & \\
\hline & 0 & & & & & 1 & \\
\hline 1 & 0 & & & & & 2 & Modified Food \\
\hline & 1 & 1 & & & & 3 & \\
\hline
\end{tabular}

Source: the authors 
Regarding the analysis by collections, it is observed that the number of texts with the theme "reduce, reuse and recycle" is considerably greater than other themes. Collection conveys 30 texts on such theme, whereas the second highest theme regarding the environment is "deforestation" gathering 14 texts, also seen in the same collection. Collection B was not ranked in the top themes, as the total number of texts was not sufficient to compare with the other ones.

Moreover, Climate Change or Global Warming, were also presented on the collections $\mathrm{C}$ and $\mathrm{D}$ with the total of 14 texts, followed by the theme sustainability with the total of 5 on collection B. This leads to the conclusion that most of the subjects are about human interfering in the environment, either helping or destroying it, which displays the idea that human, science and technology are able to solve the problems encountered in nature, which is classified as the rational perspective of environment according to Tozoni-Reis (2004).

By comparing the lower rate themes explored, the only one presented considerably higher in collection $\mathrm{B}$ than the others, was "Human behavior and Environment" with a total of 2, in the genres of song and opinion article. The naturalistic perspective in the song puts humanity responsible for damaging and disrupting the peaceful relationship with nature, contra posing the opinion article, which holds a rational perspective.
Therefore, to comprehend more about the discourse, it is necessary to observe that every text is presented in a certain format, whose characteristics are defined as genres, composed with specific language to express ideas. For that reason the following topic demonstrates the most used genres in each collection.

Regarding the genres, the analysis took place by classifying them into genres to identify which of them were dominant to teach about the environment. As language is expressed by actions through texts, which can be written, spoken, oral, or visual, the ideology is also conveyed in them, furthermore there is a chart containing each genre used to refer to the environment.

The major genres used in the analysis are pictures, public service announcements (PSA) and science popularization excerpts, followed by infographics and entries. These genres represent how textbooks are guiding students to learn about and act towards environmental issue. The language used in each text is relevant when promoting reading and interpretation. For instance, pictures can help the student to fill in the gaps of the texts, so they co-write them, become active readers, while PSAs carry plenty of ideological marks underlined. Infographics bring facts, studies, and also give the opportunity to dialogue with the reader, giving the chance of debating, questioning and investigating prior knowledge. 
Graph 1 - Total genres recontextualized in the textbooks.

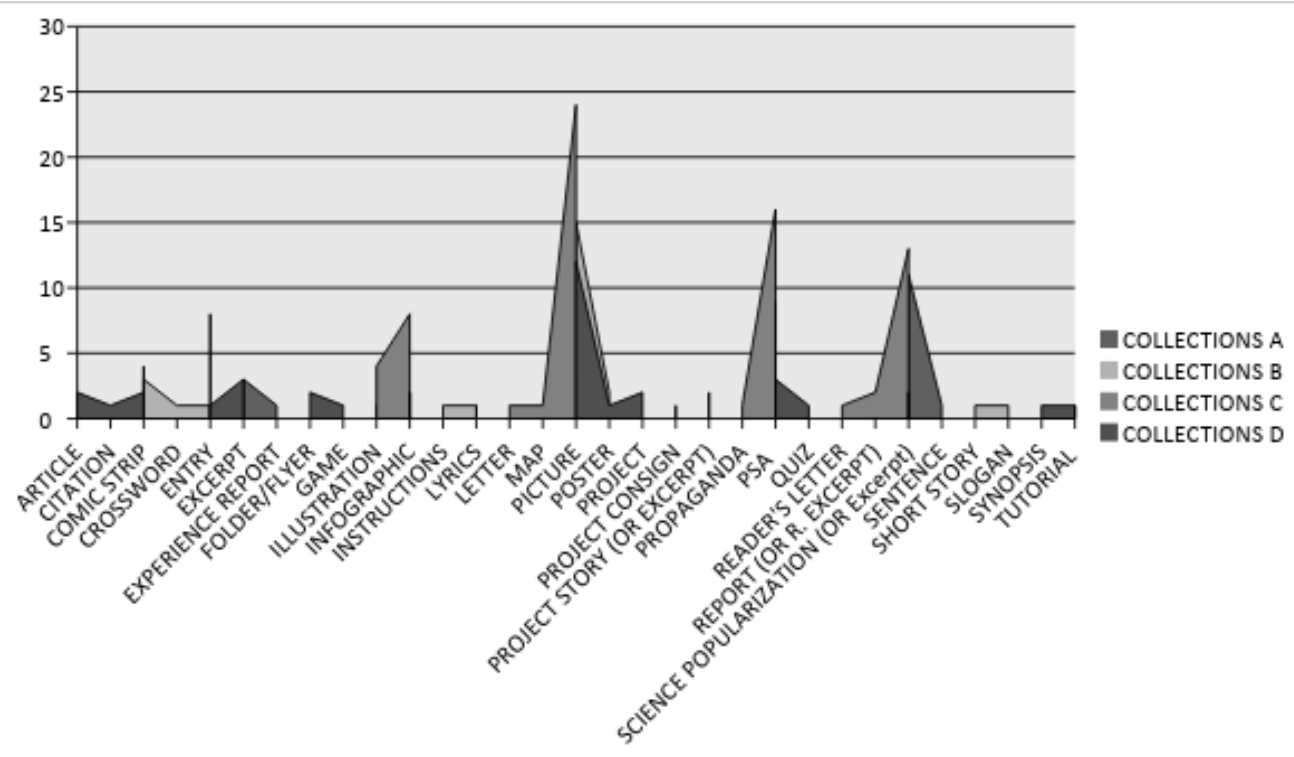

Source: the authors.

Since most of the texts do not come from online news, magazines, and blogs, which address the journalistic sphere, it is essential to investigate English textbooks discourse, to consequently understand if the students have the opportunity to enrich their knowledge about the subject, and recognize whose voices they have been learning from.

Therefore, to comprehend how much the students could interact with the texts, the writerly and readerly approach. Considering that the teacher is the one responsible to mediate the information given within the textbooks and apply them in reflexive and critical activities, they were analyzed in two perspectives, readerly or writerly. Moreover, the categories used to place them accordingly are presented in Table 4 .

Table 4 - Text classification categories for readerly or writerly

\begin{tabular}{l|l}
\multicolumn{1}{c|}{ Readerly } & \\
\hline Text is uniform & Reader is a co-producer \\
\hline Text non-negotiable & Reader is a creative interpreter \\
\hline Reader is not given a role & Text is less predictable \\
\hline Reader is an inert consumer & Reader interprets and makes his connections \\
\hline Author is the producer & Reader fills in the gaps of the text \\
\hline Text is predictable & Particular experiences and contexts are accountable \\
\cline { 1 - 1 } Text is clear and unambiguous & \\
\hline Text is not open to question & \\
\hline
\end{tabular}

Source: the authors 
According to the analyzes, most texts were classified as;

Table 5 - number of texts considered readerly and writerly

\begin{tabular}{c|c|c|c}
\hline $\begin{array}{c}\text { Book } \\
\text { Collection }\end{array}$ & Readerly & Writerly & Final Result \\
\hline A & 14 & 10 & Readerly \\
\hline B & 16 & 27 & Writerly \\
\hline C & 39 & 41 & Writerly \\
\hline D & 13 & 17 & Writerly \\
\hline
\end{tabular}

Source: the authors

It can be noticed that the number of writerly texts were predominant, specially due to the high number of images considered more open to negotiable meanings. That means students and teachers have a more engaging role which contributes for creative interpretation, development of critical thinking and connection to life experiences, furthermore taking the text from a broader concept to a local perspective.

Although the result had a positive response, it is important to highlight that the number of readerly texts were almost even to the number of writerly texts. Consequently, teachers must have the skills of creating a questioning environment to challenge the students to overcome the vision implied by the text when readerly texts are presented.

Moreover, it is also vital to draw attention to the genres used to display the texts. For instance, as observed before, photos, illustrations, lyrics, infographics, games and PSAs were more open to explore the reader's opinion and background information. On the other hand, most of the written texts were presented in the form of articles, posters, tutorials, entries and projects, directed towards the readerly approach, what would demand more effort from the teacher and students.

To analyze the text material regarding the environment and to deepen the understanding of the perspectives each text and book collection holds, this study uses the three main environmental views proposed by Tozoni Reis (2004), natural, rational and historical. To reflect upon environmental education it is necessary to comprehend what type of environmental perspectives have been taught in the classroom, as textbooks are rich in information, and full of ideologies that the teacher is responsible for administering.

By analyzing each book and collection the predominant views were: 
Table 6 - The environmental perspectives in each text by collection and level

\begin{tabular}{l|c|c|l|c|c|c|c|c}
\hline \multicolumn{1}{c|}{ Collection } & Natural & Rational & Historical & $\mathrm{R} / \mathrm{H}$ & $\mathrm{N} / \mathrm{R}$ & $\mathrm{R} / \mathrm{N}$ & $\mathrm{H} / \mathrm{N} / \mathrm{R}$ & Predominant \\
\hline Book A 1 & & 17 & & 1 & & & & Rational \\
\hline Book A 2 & & & & & & & & \\
\hline Book A 3 & & 4 & & & 1 & & 1 & Rational \\
\hline Book B 1 & & 11 & & & & & & Rational \\
\hline Book B 2 & & & & & & & & \\
\hline Book B 3 & 12 & 20 & & & & & & Rational \\
\hline Book C 1 & 5 & 33 & & & & & & Rational \\
\hline Book C 2 & & 13 & 5 & & & & & Rational \\
\hline Book C 3 & 21 & 1 & 2 & & & & & Natural \\
\hline Book D 1 & 2 & 5 & 1 & & & 3 & & Rational \\
\hline Book D 2 & 3 & & 1 & & & & & Natural \\
\hline Book D 3 & 4 & 15 & & & & & & Rational \\
\hline
\end{tabular}

Source: the authors

As presented previously, the predominant view about the environmental problems is rational, from the total amount of 177 texts. If analyzed separately, collection $\mathrm{C}$ is the book holding the highest number of rational perspective texts, with the total of 47 . Although the other books are not far behind, their numbers follow accordingly, B with 31 , A with 21 and $\mathrm{D}$ with 20 . In fact it is important to reinforce that the rational perspective believes men and technology by studies and development of sciences can find the solution for the environmental problems (Tozoni-Reis 2004).

It is relevant to recap the themes presented and their views, when recycle, reduce and reuse are the most frequent topics mentioned in all collections, followed by deforestation, pollution, and sustainability, it is evident that the rational perspective has guided the environmental education, while many other themes, as important as the ones presented are left out.

From the four collections analyzed only two had the natural view as predominant in one of the three books, but it is necessary to point out that when this perspective had its majority, the total of environmental texts regarding the naturalistic view was considerably low. The collection which presented the highest numbers is $\mathrm{C}$ with 26 texts regarding the natural perspective, followed by $\mathrm{B}$ with a total of 12 .

It is also critical to realize that the historical view is not considered as important as the other two views, knowing that learning the historical effects throughout human's life has helped not only science to improve, but also other 
areas of human development. The total of texts presented in all collections regarding the historical view is very low, with the total of 7 texts in C. If learning from past experiences is so important, why are the textbooks analysed not emphasising this perspective then?

The majority of the texts presented was from the inner circle sphere (KACHRU, 1985), where the $1^{\text {st }}$ language is English and the countries have a different reality from Brazil. The origin of the texts is extremely relevant for this research, as the influence among the textbooks development is taken into account when analyzing the dominant social discourse, regarding the natural environment. As the following graph shows the number of inner texts among expanding or outer circle are considerably higher.

Table 7 - Classification of the texts by collection

\begin{tabular}{c|c|c|c|c}
\hline Textbook collections & Inner & outer & expanding & Didactic Text \\
\hline A & 20 & & & 4 \\
\hline B & 30 & 2 & 12 & \\
\hline C & 66 & & 12 & 4 \\
\hline D & 21 & & 5 & 4 \\
\hline
\end{tabular}

Source: the authors

It is worth considering that the results above demonstrate that the inner circle dominates the environmental education in every collection. Although the research proposes to analyze the use of English to teach about the environment, it should not be forgotten that the language is used to communicate throughout the world, and many countries use it as a second language, while others use it to communicate in the business area. However, there are many other aspects that come with the language such as the construction of social representations and of our identity.

For that reason it is essential to have texts from the outer and expanding circle so as to give the reader the opportunity to comprehend and explore the world, from various cultural perspectives, to have a glimpse over environmental economy, learn about geographic aspects, different values, not favoring one nation or the other. It is interesting to see that most of the expanding texts found were pictures while written or oral texts are in majority coming from well-developed countries with a certain environmental perspective and reality. This leads to the conclusion that it is vital to promote other social contexts and realities.

Due to the results, it is showed that most of the written texts did not come from the journalistic sphere, and the goal now is to discuss about the ones that were presented in the textbooks. If 
there are many magazines, blogs, news and so on, in Brazil and around the world capable of spreading information about the topic argued, why are they not presented in the textbooks?

To answer this question, in this last part, it is fundamental to recap the influence many countries have among underdeveloped ones. The international media has such a powerful influence on legislation that after 1975 when the Belgrade Letter was written, talking about the areas in where the environmental education should be taught, many other conferences took place. For instance in 1976 UNESCO refers to English language and environmental education in a way of mutual contribution about natural environmental problems.

Therefore tables 8 and 9 show the support used to gather the texts used in each collection, and the websites commonly used by them.

Table 8 - Type of support found by collection

\begin{tabular}{c|c|c|c|c}
\hline \multicolumn{5}{c}{ Support } \\
\hline Collection & Institutional & Media & Community & Others (book and quote) \\
\hline A & 14 & 4 & & 6 \\
\hline B & 37 & 5 & & 1 \\
\hline C & 66 & 9 & & 5 \\
\hline D & 25 & 2 & & 3 \\
\hline
\end{tabular}

Source: the authors

Due to the analyzes, the most used type of support is institutional, this means that only 20 texts came from the media support, while 142 are from the institutional websites. The institutional websites are composed by public and private organizations, ongs, government, volunteer movements, and education.
The media support characterizes blogs, news, magazines, flogs and etc, these are the types of support this research proposed to analyze, to determine the influence and predominant discourse mainly on the environmental education through English texts in the Primary education. 
Table 9 - The list contains the names of the media websites found, and their views:

\begin{tabular}{l|c|c|c|c|l}
\hline \multicolumn{1}{c|}{ Website Hoster } & View & Country & Circle & Type of Support & \multicolumn{1}{|c}{ Genre } \\
\hline Wall Street Journal & Rational & USA & Inner & Newspaper & PSA \\
\hline The Times & Rational & UK & Inner & Newspaper & Science Popul. \\
\hline First News & Rational & UK & Inner & News magazine & Project Consign \\
\hline TIME & Rational & USA & Inner & Newspaper & Article excerpt \\
\hline The New York Times (2x) & Rational & USA & Inner & Newspaper & $\begin{array}{l}\text { News article and } \\
\text { reader's letter }\end{array}$ \\
\hline Mongobay (2x) & Natural & USA & Inner & News & $\begin{array}{l}\text { Infographic and } \\
\text { Map }\end{array}$ \\
\hline USA Today & Rational & USA & Inner & News & Infographic \\
\hline uktv.co.uk & Rational & UK & Inner & News & Tutorial \\
\hline 4.bp.blogspot.com & Natural & not identified & $\begin{array}{c}\text { not } \\
\text { identified }\end{array}$ & blog & PSA \\
\hline Natural News & Natural & USA & Inner & News & Comic strip \\
\hline Go Green Guyz & Natural & not identified & not & Blog & Slogan \\
\hline The Drum & Rational & Scotland & Inner & Magazine & PSA \\
\hline Infographics Archive & Rational & Netherlands & & Blog & Infographic \\
\hline OSOM & Natural & USA & Inner & Blog & Picture \\
\hline Agência O Globo & Rational & Brazil & & Magazine & Picture \\
\hline publishaletter.com & Rational & USA & Inner & News/magazine & Reader's letter \\
\hline Soure: the author & \multicolumn{1}{|c|}{} & & &
\end{tabular}

Source: the authors

Firstly, it is surprising to notice that there is a small number of media texts found in the English books about the environment, in contrast with the amount of news, studies and articles written about the subject. As a result of the analyses the majority of the media texts comes from the inner circle, gathering about 12 , mainly from the United States and United Kingdom. This leads to the conclusion that the social reality, economical system, and culture are guided by the rational perspective, with a total of 11 texts in the media hosters. Only two of them come from outer circle, using the natural perspective, they are both from
Brazil and were presented in the genre of pictures.

The problem originates when the influential media limits the education promoted in the classroom, by the reading and interpretation of the subject within the didactic material, in this case the environment. Therefore it is essential to highlight the perspective left aside, in this case the historical, what could conduct the critical environmental education by providing facts learnt throughout history, finding ways to overcome the problems caused by the lack of knowledge and understanding. 
Many other journalistic texts could be found in the English textbooks, such as the East African Standard (Kenya), Beira Post (Mozambique), Lagos Standard (Nigeria), Cape Times (South Africa), which are all offered in English. Furthermore, even Brazilian news is published in English, such as Folha de São Paulo, the Global Warming Blog, and the Rio Times, all outer and expanding circle that could promote a broader perspective of the environment.

\section{Conclusion}

The considerations presented by this paper focused on the environmental discourse that circulates in the school sphere through its presence in didactic books, based on Bazerman's theoretical assumption (2009) that the teacher's actions as a mediator of literacy encounters the use of texts, written or oral, and by means of intertextuality to promote the reader's consciousness and commitment to engage in the natural environment conservation. Moreover, bearing in mind the UNESCO guidelines propose where $\mathrm{EE}$ is seen as a process that progresses from consciousness, comprehension, concern, skills development to the proposal of solutions and participation, and using the language to develop critical thinking, improve science, environmental awareness, and environmental literacy.

Our data were gathered composed by mapping the environmental discourse constituted on the four pedagogical collections approved by the National
Program of the Didactic Book for high school regarding the years of 2015, 2016 and 2017. The analyses were done by the identification of the themes, genres, support as well as the concept of readerly or writerly and the recognition of the view of environmental education underlying such texts and their recontextualization into the textbooks.

To identify the journalistic texts we opted for a micro approach rather than macro, beginning from the ones presented in the text, what facilitated the search and understanding of the perspectives taught through the texts, and to identify discursively the social actors who constitute and legitimize the discourse.

The journalistic news, articles, and facts are almost absent in the didactic material, which makes us reflect upon such result; if these texts are so relevant to shape the social identity of a citizen, what is also necessary for the students that are being prepared to face the "vestibular" ${ }^{3}$ why are they the minority? One important reason is because news is so easily and quickly outdated. Nevertheless, the selection could include facts as reported in different points of view to generate discussion, doubt, need for new searches.

As presented in this work, the educational acts are mostly focused on the rational perspective, what demonstrates that instead of learning about the origin of the environmental problems, the economic, social, political and cultural effects caused by them through the historical perspective, the approach taken 
is to underlie on scientific knowledge and the human force to overcome them.

When the inner circle countries view of the environment is predominant, many aspects of the society is disregarded, and a lot of problems are caused, in some aspects by the industrialization and economy, and others such as local cultural practices and politics.

Certainly, if it would be given more opportunities to the students and teachers to debate, argument, reflect, learn and share, by writerly texts to promote the reader a role, and the possibility of being the author of his or her own life, by making decisions and taking actions, engaging consciously and collaborating with the community, so that the EE would achieve its goals.

\section{O discurso ambiental (da esfera jornalística) e sua recontextualização em materiais didáticos de inglês no Brasil}

\section{Resumo}

Este artigo objetiva investigar textos abordando o discurso ambiental em livros didáticos de língua inglesa e as implicações para a educação. Os dados são gerados por meio de i) levantamento dos textos presentes nas coleções didáticas aprovadas pelo PNLD 2015/EM; e ii) identificação da visão de meio ambiente e das características dos textos selecionados em relação ao gênero, suporte, tema, e contexto de produção. Os resultados mostram que a visão racional preva- lece, o suporte institucional foi o predominante e a fonte majoritária dos textos foi do círculo interno. Como implicações destacamos: i) o uso de imagens promove espaços para letramentos (críticos) podendo forjar a construção de novas significações; ii) o predomínio de textos do círculo interno afasta o aluno de visões periféricas e do uso da língua inglesa como língua franca/internacional; iii) a ênfase na visão racional mantém a tecnologia e ações técnicas e/ou tecnológicas como solução para problemas ambientais.

Palavras-chaves: discurso ambiental; material didático; língua inglesa.

\section{Notas}

1 Acknowledgments: This article was conceived under the Research Project "SOCIAL AND DISCURSIVE PRACTICES ABOUT THE ENVIRONMENT IN GLOBALIZED TIMES: IMPLICATIONS AND PERSPECTIVES FOR EDUCATION IN A FOREIGN LANGUAGE”, registered at the State University of Londrina (Londrina, Brazil), number 10171. Thanks to the Brazilian National Council for Scientific and Technological Development $(\mathrm{CNPq})$ for the financial resource during the period of 1 March 2016 to 28 February 2019 related to the validity of the research productivity (PQ2) grant to the second author, case no. 308754/2015-8 as well as a scholarship for research initiation (PROIC-UEL) for the first author. Thanks to Bruno Silva Sanches and Maruen Francischini for the review.

2 According to MEC, the PNLD main goal is to subsidize the pedagogical teaching practices through the distribution of textbook collections for basic education. Although it is one of the oldest programs in Brazilian public education aiming at public education, the component of modern foreign language was only included in in the year 2009, resulting on the Didactic Guide Books: PNLD 2011(BRASIL, 2010).

3 Vestibular is an exam which Brazilian Public Universities apply in order to select candidates willing to start an university degree. 


\section{References}

BALL, S. J.; BOWE, R. Subject departments and the 'implementation' of National Curriculum policy: an overview of the issues. Journal of Curriculum Studies, v. 24, n. 2, p. 97-115, 1992.

BARTHES, R. The Death of the Author. In J. Cauchie (ed) Theories of Authorship. London Routledge. 1981.

BAZERMAN, C. Gêneros textuais, tipificação e interação. Organizado por Angela Paiva Dionísio e Judith Chambliss Hoffnagel. São Paulo: Cortez, 2005.

. Scientific Knowledge, public knowledge, and public policy: genre formation and disruption of knowledge for acting about global warming. SIMPÓSIO INTERNACIONAL DE ESTUDOS DE GENNEROS TEXTUAIS, V. Anais. Caxias do Sul, 2009.

BAWARSHI, A. S.; REIFF, M. J. (2010). Genre: an introduction to history, theory, research, and pedagogy. West Lafayette, Ind, Parlor Press.

BOLTON, K.; KACHRU, B. B. World Englishes: Critical Concepts in Linguistic. Taylor \& Francis, v. 3. 2006.

BONINI, A. Mídia/suporte e hipergênero: os gêneros textuais e suas relações. RBLA, Belo Horizonte, v. 11, n. 3, 2011, p. 679-704.

BRASIL. Lei n. 9.795, de 27 de abril de 1999. Institui a política nacional de educação ambiental. Diário Oficial da União, Brasília, DF, 28 abr. 1999. Disponível em: http:// www.planalto.gov.br/ccivil_03/leis/19795.htm Acesso em: 28 abr. 2013.

BRONCKART, J.-P. Atividade de linguagem, textos e discursos: por um interacionismo sociodiscursivo. Tradução de Anna Rachel Machado e Péricles Cunha. São Paulo: Educ, 1999
CARSON, R. Primavera Silenciosa. Traduzido por Raul de Polillo, 2. ed. São Paulo: Melhoramentos, 1969.

CRISTOVÃO, V. L. L. A Genre-Based Approach Underlying Didatic Sequences for the Teaching of Languages. In: ARTEMEVA, Natasha; FREEDMAN, Aviva. (Org.). Genre Studies Around the Globe: beyond the three traditions. 1ed. San Bernardino, CA: Inkshed Publications, 2015, v. 1, p. 403-452.

DOLZ, J.; SCHNEUWLY, B. Gêneros orais e escritos na escola. Campinas: Mercado de Letras, 2004.

HALL, K. An analysis of primary literacy policy in England using Barthes' notion of 'readerly' and 'writerly' texts. v. 1. Sage Publications, 2001.

KACHRU, B. B. Standards, codification and sociolinguistic realism: the English language in the outer circle. In: QUIRK, R.; WIDDOWSON, H. (Eds.). English in the world: teaching and learning the language and literatures. Cambridge: Cambridge University Press, 1985. p. 11-30.

MARCUSCHI, L. A. Gêneros textuais: definição e funcionalidade. In: DIONÍSIO, A. P.; MACHADO, A. R.; BEZERRA, M. A. (Org.) Gêneros textuais e ensino. Rio de Janeiro: Lucerna, 2002.

TOZONI-REIS, M. F. de C. Educação ambiental: natureza, razão e história. Campinas: Autores Associados, 2004.

UNESCO-UNEP. 'The Belgrade Charter: A global framework for environmental education'. Connect v. 1, n. 1, p. 1-9, 1976.

RICHARDSON, R.J. Pesquisa social: métodos e técnicas. 3. ed., São Paulo: Atlas, 2007. 